\title{
Empirical investigation of the associations of technological capability, logistics capability and supply chain management strategies with competitive advantage: Evidence from Saudi manufacturers
}

\author{
Omar Ali Bagais ${ }^{\mathrm{a}^{*}}$ and Khaled Salmen Aljaaidi ${ }^{\mathrm{a}}$
}

\section{A B S T R A C T}

\begin{abstract}
The objective of this study is to empirically evaluate the associations of information technology, supply chain management, and logistic capability with a competitive advantage of some Saudi Arabia industry during the year of 2020 using Resource-based Theory. Using the information from a self-administered survey with an ultimate sample of 118 respondents, the outcome of Multiple Regression indicates a significant positive correlations of information technology, supply chain management, and logistics capabilities strategies with a competitive advantage. The outcome of this study should be applied by the company's top management to improve their supply chain management within strategic plans, as a result, increase the magnitude of their competitive advantage and financial performance.
\end{abstract}

\section{Introduction}

The ability of a company to handle technology and changes associated with it is referred to as technological capability (Lall, 1993). In any firm, the objective of information technology is to reduce the cost and increase capability (Closs et al., 1997). However, there are challenges affecting organizations implementing information technology (IT), including lack of IT experts, complex and complication of IT applications, IT application cost, and determination of outsourcing as well as IT strategy (Handfield \& Withers, 1993; Dawe, 1994; Zulkiffli, 2010). Besides, Bowersox et al. (1989), Closs et al. (1997), and Burgess (1998) suggest that IT is reviewed as a milestone in safeguarding supply management from failure. IT can reduce costs and enhance the quality of services at the same time, and improve the profitability of a firm. It also enables firms to share sensitive, useful, and accurate information on time with supply chain partners. Consequently, this can improve supply chain coordination associated with the success of partnerships in the supply chain (Bowersox et al., 1990; Cooper \& Gardner, 1993; Lambert et al., 1996). Nowadays, firms are using their ability of the strategic plan to attain competitive advantage in the market place, including strategies of supply chain management and logistics capabilities (Olavarrieta \& Ellinger, 1997). According to Ellinger et al. (2000), correlation between performance and logistical capability accommodates the incorporation with other financial areas of the firm, including operations, marketing, and finance. Sezhiyan, Page and Iskanius (2011) suggest that there exists a positive relationship between the performance of a firm and logistic capabilities. In their study, they exhibited that companies have to consider logistic capability to maintain a remarkable competitive advantage and high-performance level. Also, the managers have the responsibility of reviewing logistic capabilities, including market coverage, pre- and post-sales services, low-cost distribution, and prompt delivery. Capabilities such as quality service, delivery speed, flexibility, cost, and innovation can improve the performance of an

* Corresponding author

E-mail address: k.aljaaidi@psau.edu.sa (O. A. Bagais)

(C) 2020 by the authors; licensee Growing Science. doi: $10.5267 / \mathrm{j}$.uscm.2020.6.007 
organization (Fawcett \& Fawcett, 1995). Besides, there exists a positive correlation between logic capabilities and performance of market and finance (Zhao et al., 2001; Olavarrieta \& Ellinger, 1997; Hayes \& Pisano, 1994; Morash, Droge and Vickery, 1996; Cho et al., 2008). Green et al. (2006) suggest that supply chain management is a vital management strategic mechanism that improves the competitive advantage of a firm. It is reported that the improvement of strategies in supply chain management has a positive influence on the company's operations (Sezhiyan, Page and Iskanius, 2011; Armistead \& Maps, 1993; Bowersox \& Closs, 1996; Oliver \& Delbridge, 2002; Tan, 2002). According to Lummus and Alber (1997), the companies have to balance between their supply chain capabilities and what the customers expect. In particular, the ability of company management to initiate a strong relationship with its customers and suppliers is the first step to achieve a competitive advantage (Tyndall, 1988).

\subsection{Problem statement}

Various empirical researches explored the correlation of logistic capabilities, supply chain management, and information technology with competitive advantage in already developed and developing countries. Based on the awareness of the researchers, a study evaluating these issues in Saudi Arabia context does not exist. Applying the perspective of resourcebased theory, the objective of this study is to explore the correlation between information technology, logistics capabilities, as well as supply chain management with a competitive advantage in some industry in Saudi Arabia. The research involves the following testable hypotheses stated in direct forms:

$H_{1}:$ There is a positive association between information technology and competitive advantage.

$\mathrm{H}_{2}$ : There is a positive association between logistics capability and competitive advantage.

$H_{3}$ : There is a positive association between supply chain management and competitive advantage.

This research is organized as follows; section two highlights the methodology, section three introduces the empirical findings, and the last section consists of the conclusion.

\section{Methodology}

In accordance to the existing study's results and reasoning associated with supply chain management (Sezhiyan, Page and Iskanius, 2011; Armistead and Maps, 1993; Bowersox and Closs, 1996; Oliver and Delbridge, 2002; Tan, 2002), logistics capability (Zhao et al., 2001; Olavarrieta and Ellinger, 1997; Hayes and Pisano, 1994; Morash, Droge and Vickery, 1996; Cho et al., 2008; Sezhiyan, Page \& Iskanius, 2011; Ul-Hameed et al., 2019), and information technology (Shang \& Marlow, 2005; Lall, 1993; Closs et al., 1997; Handfield \& Withers, 1993; Dawe, 1994; Zulkiffli, 2010; Bowersox et al., 1990; Cooper and Gardner, 1993; Lambert et al., 1996; Burgess, 1998; Sharma \& Singh, 2013), the purpose of developing the following conceptual model is to show the predicted relations as illustrated in Fig. 1.

Independent variables

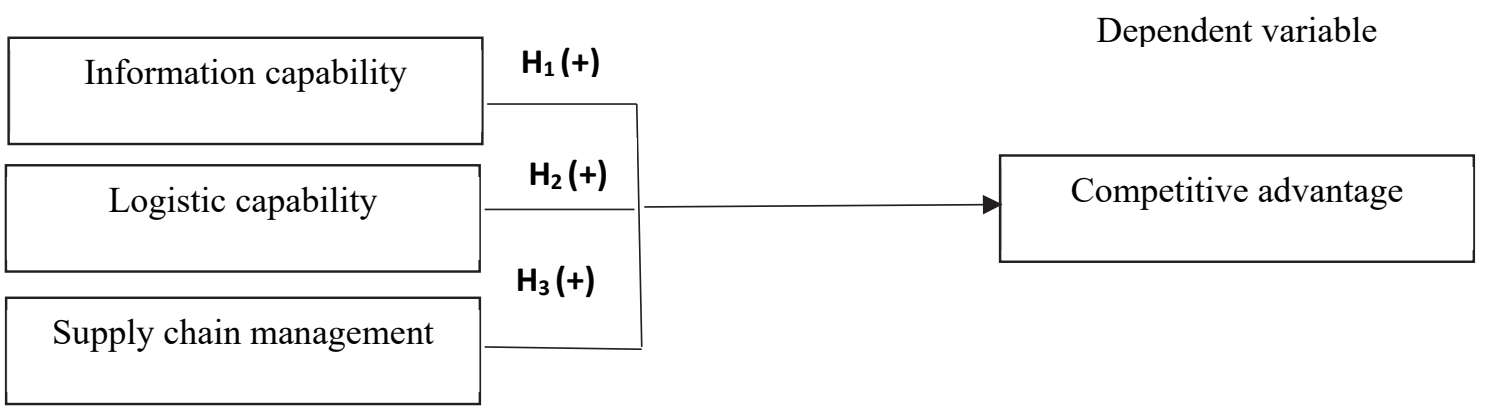

Fig. 1. Research model of the study

The selected industry in this study is in Saudi Arabia for the year 2020. A quantitative method is preferred for this study as the most useful and popular design of conducting a survey or field research. The use of a questionnaire survey to collect data is a suitable instrument to answer the established research questions, that is, "To what extent do information technology, logistics capability, and supply chain management are associated with a competitive advantage in X industry in Saudi Arabia?" Besides, there is a need to choose a survey as it entails surveying respondents as well as documenting their responses for analysis purposes. The model implemented in this research is adapted and validated from Zulkiffli (2010), Shan and Marlow (2005), Wisner (2003), Morash et al. (1996), Cho et al. (2008) and Sezhiyan et al. (2011), Fynes and Voss (2002), Zhang et al. (2006), Slater and Narver, (2000). Supply chain management, information technology, and 
logistics capability are tested empirically with competitive advantage to establish the degree to which information technology, logistics capability, and supply chain management affect the magnitude of the competitive advantage. Information technology, logistic capability, and supply chain management have been used as independent variables, while competitive advantage is the dependent variable in this model. After translating from English, the questionnaire was administered to the study's sample in Arabic language. The questionnaire of this research consists of five sections: the first section, A, comprises of respondent's demographic data. The survey has demographic variables, including age, gender, job position, and academic qualification. The second section, B, measures the company's information capability, which is 4items applying a five-point Likert Scale. The range of the five-point Likert Scale is from 1 (very important), illustrating to the lowermost concerns/issues of the firm's logistics capability, to 5 (high importance), showing to the highest concerns/issues of the organization's information capability. The third section, C, measures the company's logistic capability, including 4-items applying a five-point Likert Scale. The range of the five-point Likert Scale is from 1 (very important), showing to the lowermost concerns/issues of the firm's logistic capability, to 5 (high importance), exhibiting to the highest concerns/issues of the organization's logistics capability. The fourth section, D, measures supply chain management of the firm, which is 4-items applying a five-point Likert Scale. The range of five-point Likert Scale is 1(very important), illustrating lowermost concerns/issues of the firm's supply chain management, to 5 (high importance), showing to the highest concern/issues of the organization's supply management. The last section, F, measures the company's competitive advantage, which is 5-items applying a five-point Likert Scale. The range of the five-point Likert Scale is from 1 (very important), showing to the lowermost concerns/issues of the firm's competitive advantage, to 5 (high importance), illustrating to the highest concern/issues of the organization's competitive advantage. For the distribution of questionnaires, different key individuals are chosen as a sample subject representing the most appropriate ones in giving out information regarding the dimensions of the research, including managing director, chief executive officer, logistics manager, supply chain manager, and marketing or operations manager. The electronic survey is designed using google forms to enhance easy distribution to the sample. The participants were given two weeks to return a filled-in survey. As a result of this technique, 118 respondents were available to obtain information. This research uses the Multiple Regression Model. The nominal values were allocated to measure the dependent and independent variables. In specific, the model can be demonstrated as:

$$
\mathrm{CA}(\mathrm{Y})=\beta_{0}+\beta_{1} \mathrm{X}_{1}+\beta_{2} \mathrm{X}_{1}+\beta_{3} \mathrm{X}_{1}+\mathrm{e}
$$

where the dependent variable is:

$\mathrm{CA}(\mathrm{Y})=$ competitive advantage (significance at level 0.05).

where the independent variables are:

$$
\begin{aligned}
& X_{1}=\text { information capability } \\
& X_{2}=\text { logistics capability } \\
& X_{3}=\text { supply chain management } \\
& \text { e } \quad=\text { Error term. }
\end{aligned}
$$

SPSS version for Windows was used to complete data analysis. To describe the demographic variables, an analysis of descriptive statistics using frequencies and percentages was used. The research question was addressed using a simple regression.

\section{Empirical findings}

In order to run the multiple regression successfully, the dependent and independent variables were checked for their reliability using Crobach's Alpha. In this study, the Cronbach's Alpha coefficient used is based on the average correlation of items within a test if the items are standardized. The reliability test shows the Cronbach's Alpha coefficients. The instruments are reasonably accepted for the purpose of reliability as depicted in Table 1:

Table 1

Reliability test

\begin{tabular}{clc}
\hline Variables' abbrev. & Variables' names & Alpha \\
\hline IC & Information capability & .662 \\
LC & Logistics capability & .642 \\
SCM & Supply chain management & .636 \\
CA & Competitive advantage & .669 \\
\hline
\end{tabular}


Multiple Regression was used to evaluate the level of association of information capability, logistics capability, supply chain management and competitive advantage. As shown by Table 2, the $\mathrm{R}^{2}$ is 0.731 which means that this model has explained $73.1 \%$ of the total variance in the competitive advantage.

Table 2

Model Summary

\begin{tabular}{ccccc}
\hline Model & R & R Square & Adjusted R Square & Std. Error of the Estimate \\
\hline 1 & .855 & .731 & .724 & .5004 \\
\hline
\end{tabular}

Table 3 depicts that the $F$-value for the model is statistically significant at the $1 \%$ level which means that the overall model can be interpreted.

Table 3

ANOVA Analysis

\begin{tabular}{ccccc}
\hline \multirow{2}{*}{1} & & Model & F & Sig. \\
\cline { 2 - 5 } & Regression & & 103.503 & $.000^{\mathrm{b}}$ \\
\hline
\end{tabular}

Table 4 illustrates the Multiple Regression results. As shown by Table 4 that there is a significant and positive association between information capability and competitive advantage $\left(\beta=.401, t=4.356, P=.000\right.$, one-tailed significance). Thus, $\mathrm{H}_{1}$ is supported. This result gives a support to the previous studies (Shang and Marlow, 2005; Lall, 1993; Closs et al., 1997; Handfield and Withers, 1993; Dawe, 1994; Zulkiffli, 2010; Bowersox et al., 1990; Cooper and Gardner, 1993; Lambert et al., 1996; Burgess, 1998).

Table 4

Multiple Regression

\begin{tabular}{lccccc}
\hline Variables & Coeff. & t & p-value & Tolerance & VIF \\
\hline (Constant) & & .016 & .987 & & \\
Test variables & & & & & \\
IC & .401 & 4.356 & .000 & .278 & 3.595 \\
LC & .352 & 4.983 & .000 & .472 & 2.117 \\
SCM & .186 & 2.014 & .046 & .275 & 3.637 \\
\hline
\end{tabular}

As shown by Table 4 that there is a significant association between logistics capability and competitive advantage $(\beta=.352$, $t=4.983, P=.000$, one-tailed significance). Thus, $\mathrm{H}_{2}$ is supported. This result gives a support to the previous studies (Zhao et al., 2001; Olavarrieta and Ellinger, 1997; Hayes and Pisano, 1994; Morash, Droge and Vickery, 1996; Cho et al., 2008; Sezhiyan, Page \& Iskanius, 2011). As for the association of supply chain management with competitive advantage, a significantly positive association was reported $(\beta=.186, t=2.014, P=.046$, one-tailed significance). Therefore, hypothesis $\mathrm{H}_{3}$ is accepted. This result gives support to the findings of the previous studies (Sezhiyan, Page and Iskanius, 2011; Armistead and Maps, 1993; Bowersox and Closs, 1996; Oliver and Delbridge, 2002; Tan, 2002).

\section{Conclusion}

The objective of this research was to evaluate the relation of logistics capability, information capability, and supply chain management with a competitive advantage among 118 participants in the X industry in Saudi Arabia for the year 2020 . The research discovers that information capability, logistics capability, and supply chain management correlate positively with a competitive advantage. This presents Saudi X industry with an opportunity to improve their strategies of information capability, logistics capability, and supply chain management as a fundamental management strategy tool, which as a result, would enhance the competitive market advantage of the industry and impact their performance in a positive way. Besides, the $\mathrm{X}$ industry has the opportunity to review balancing its relationship with the customers and suppliers at the same time. Therefore, it can improve their financial performance. The outcomes of this research are essential to the top management to incorporate strategies of supply chain management within their firm's strategic plan. This study has achieved its objectives; however, some challenges still exist. This research can be duplicated using information from other industries. Consequently, the new independent variables can be added to the model, including supply effort management, benchmarking, and competitive capabilities. Therefore, these limitations may act as an obstacle to the generalization of the results of this research to other countries or sectors. 
This publication was supported by the Deanship of Scientific Research at Prince Sattam bin Abdulaziz University, Alkharj, Saudi Arabia.

\section{References}

Armistead, C., \& Mapes, J. (1993). The impact of supply chain integration on operating performance. Logistics Information Management 6(4), 9-14

Bowersox, D.J., \& Closs, D.J. (1996). Logistics Management: The Integrated Supply Chain Process. International ed., McGraw-Hill, Singapore.

Cho, J. J.-K., Ozment, J. \& Sink, H. (2008). Logistics capability, logistics outsourcing and firm performance in an ecommerce market. International Journal of Physical Distribution \& Logistics Management, 38(5), 336-359.

Closs, D. J., Goldsby, T. J. \& Clinton, S. R. (1997). Information technology influences on world class logistics capability. International Journal of Physical Distribution \& Logistics Management, 27(1), 4-17.

Cooper, M. C., \& Gardner, J. T. (1993). Building good business relationships: more than just partnering or strategic alliances? International Journal of Physical Distribution \& Logistics Management, 23(6), 14-26.

Dawe, R. L. (1994). An investigation of the pace and determination of information technology use in the manufacturing materials logistics system. Journal of Business Logistics, 15(1), 229-259.

Fawcett, S. E., \& Fawcett, S. A. (1995). The firm as a value-added system. International Journal of Physical Distribution \& Logistics Management, 21(1), 23-33

Fynes, B., \& Voss, C. (2002). The moderating effect of buyer-supplier relationships on quality practices and performance', International Journal of Operations and Production Management, 22(6), 589-613.

Green, K. W., McGaughey, R., \& Casey, K. M. (2006). Does supply chain management strategy mediate the association between market orientation and organizational performance? Supply Chain Management: An International Journal 11(5), 83-94.

Handfield, R. B. \& Withers, B. (1993). A comparison of logistics management in Hungary, China, Korea, and Japan. Journal of Business Logistics, 14(1), 81-109.

Hayes, R. H., \& Pisano, G. P. (1994). Beyond world-class: the new manufacturing strategy. Harvard business review, 72(1), 77-86.

Lall, S. (1993). Understanding technology development. Development and Change, 24(4), 719-753.

Lambert, D.M., Stock, J.R., \& Ellram, L.M. (1998). Fundamentals of Logistics Management. Irwin/McGraw-Hill, Singapore.

Lummus, R., \& Alber, K. (1997). Supply Chain Management: Balancing the Supply Chain with Customer Demand, APICS Educational and Research Foundation Research Paper Series, (707010), January.

Morash, E. A. (2001). Supply chain strategies, capabilities, and performance. Transportation Journal, 41(1), 37-54.

Olavarrieta, S., \& Ellinger, A. E. (1997). Resource-based theory and strategic logistics research. International Journal of Physical Distribution \& Logistics Management, 27, 559-587.

Oliver, N., \& Delbridge, R. (2002). The characteristics of high performing supply chains. International Journal of Technology Management, 23(1-3).

Sezhiyan, D. M., Page, T., \& Iskanius, P. (2011). The impact of supply effort management, logistics capability, and supply chain management strategies on firm performance. International Journal of Electronic Transport, 1(1), 26-44.

Shang, K. \& Marlow. (2005). Logistics capability and performance in Taiwan's major manufacturing firms. Transportation Research Part E, 41, 217-234.

Sharma, S., \& Singh, G. (2013). Reverse logistics: Design implications on the basis of product types sharing identical supply chain member motivations. Uncertain Supply Chain Management, 1(1), 33-44.

Slater, S.F., \& Narver, J.C. (2000). Intelligence generation and superior customer value. Journal of the Academy of Marketing Science, 28(1), 20-35.

Tan, K.C. (2002). Supply chain management: practices, concerns, and performance issues. Journal of Supply Chain Management, 38(1).

Tyndall, G.R. (1988). Supply-chain management innovations spur long-term strategic retail alliances. Marketing News, 22(26).

Ul-Hameed, W., Shabbir, M., Imran, M., Raza, A., \& Salman, R. (2019). Remedies of low performance among Pakistani e-logistic companies: The role of firm's IT capability and information communication technology (ICT). Uncertain Supply Chain Management, 7(2), 369-380.

Wisner, J.D. (2003). A structural equation model of supply chain management strategies and firm performance. Journal of Business Logistics, 24(1), 1-26.

Zhang, F.J., Tian, Y.Z., Sun, X.L. (2006). Empirical analysis of the effects of supplier selection and integration on customer satisfaction and business performance. IEEE Conference Proceedings, pp.931-935, IEEE Singapore.

Zhao, M., Dröge, C., \& Stank, T. P. (2001). The effects of logistics capabilities on firm performance: customer-focused versus information-focused capabilities. Journal of Business Logistics, 22(2), 91-107.

Zulkiffli, S. N. A. (2010). The impact of supply chain operational capabilities on business performance of small and medium enterprises in Malaysia: a preliminary analysis. International Journal of Business and Management Science, 3(2), 1. 
(C) 2020 by the authors; licensee Growing Science, Canada. This is an open access article distributed under the terms and conditions of the Creative Commons Attribution (CC-BY) license (http://creativecommons.org/licenses/by/4.0/). 